\title{
PEMENUHAN LAYANAN PEMBELAJARAN BAGI SISWA PENGHAYAT KEPERCAYAAN DI WILAYAH DINAS PENDIDIKAN KABUPATEN BANTUL
}

\author{
Ulfhia Dewi Putri \& Yitno Pringgowijoyo \\ Universitas PGRI Yogyakarta \\ ulfhiadewi@gmail.com
}

\begin{abstract}
Abstrak
Penulisan penelitian ini yang pertama bertujuan untuk mengetahui kebijakan pemerintah tentang pendidikan keagamaan bagi Penghayat Kepercayaan. Kedua ingin mengetahui pelaksanaan pemenuhan layanan pembelajaran pendidikan bagi Penghayat Kepercayaan di wilayah Dinas Pendidikan Kabupaten Bantul. Penelitian ini dilakukan di satuan pendidikan atau sekolah yang berada di wilayah Dinas Penidikan Kabupaten Bantul. Penelitian ini menggunakan penedekatan kualitatif, sebagaimana prosedur penelitian yang menghasilkan data deskriptif berupa kata-kata tertulis maupun lisan dari narasumber yang diamati. Pendekatan ini diharapkan mampu menyesuaikan realita di lapangan dengan teknil mengumpulkan data secara langsung di lapangan melalui dokumen, wawancara, observasi dan kajian pustaka. Analisis data tahap berikutnya dari pengumpulan data kemudian reduksidata, penyajian data dan terakir yaitu penarikan kesimpulan. Subjek yang diteliti adalah 3 narasumer yaitu 1 Guru Penghayat Kepercayaan dan 2 siswa Penghayat Kepercayaan. Hasil dari penelitian ini bahwa kebijakan pemerintah tentang pendidikan bagi Penghayat Kepercayaan. Kebijakan tersebut sudah diatur dalam Peraturan Menteri Pendidikan dan Kebudayaan Republik Indonesia Nomor 27 tahun 2016 tentang Layanan Pendidikan Kepercayaan Terhadap Tuhan Yang Maha Esa Pada Satuan Pendidikan dan pelaksanaan pemenuhan layanan pembelajaran pendidikan bagi Penghayat Kepercayaan di wilayah Dinas Pendidikan Kabupaten Bantul tepatnya berlokasi di SMK Negeri 1 Kasihan, belum sepenuhnya terpenuhi layanan pembelajaran pendidikannya.

Kata Kunci: Layanan pembelajaran, Penghayat Kepercayaan, Dinas Pendidikan Kabupaten Bantul
\end{abstract}

\begin{abstract}
The writing of this study was the first to find out the government's policy on religious education for believers. The second wants to know the implementation of the fulfillment of educational learning services for Believers in the bantul district education office. This research was conducted in education units or schools located in the area of Bantul District Education Office. This study uses qualitative approaching, as well as research procedures that produce descriptive data in the form of written and oral words from the observed source. This approach is expected to adjust the reality in the field by collecting data directly in the field through documents, interviews, observations and literature studies. Analysis of the next stage of data collection then reduction of data, presentation of data and the last is the withdrawal of conclusions. The subjects studied were 3 speakers, namely 1 Trust Teacher and 2 Students of Penghayat Kepercayaan. The result of this study is that the government's policy on education for believers. The policy has been stipulated in the Regulation of the Minister of Education and Culture of the Republic of Indonesia Number 27 of 2016 concerning The Service of Education Trust in God almighty in the Education Unit and the implementation of the fulfillment of educational learning services for Believers in the area of the Education Office of Bantul Regency precisely located in SMK Negeri 1 Kasihan, has not fully fulfilled its educational learning services.
\end{abstract}

Keywords: Learning services, Believers, Education Office of Bantul Regency

\section{PENDAHULUAN}

Pasal 5 ayat 1 Undang-Undang Nomor 20 Tahun 2003 tentang Sistem Pendidikan Nasional menegaskan bahwa setiap warga negara mempunyai hak yang sama untuk memperoleh pendidikan yang bermutu dan dalam pasal 5 ayat 3 Undang-Undang tersebut juga menjelaskan mengenai daerah yang terpencil berhak memperoleh pendidikakan layanan khusus. Masalah 
pendidikan keagamaan pada UndangUndang Nomor 20 Tahun 2003 tentang Sistem Pendidikan Nasional dalam pasal 12 ayat 1 menjelaskan bahwa setiap peserta didik disetiap satuan pendidikan berhak mendapatkan pendidikan agama sesuai dengan agama yang dianutnya dan diajarkan oleh pendidik sesuai dengan agama yang seagama selain itu juga mendapatkan pelayanan pendidikan sesuai bakat, minat dan kemampuannya. Pendidikan dapat diartikan sebagai proses interaksi belajar mengajar dalam bentuk yang formal mencakup interaksi individu dengan lingkungannya yang mengubah sikap dan tata laku seseorang maupun kelompok dalam usaha mendewasakan manusia.

Dalam Kamus Besar Bahasa Indonesia pendidikan berasal dari kata didik yaitu memelihara dan memberi latihan yang mengenai akhlak dan kecerdasan pikiran. Pendidikan umumnya adalah upaya untuk memajukan pertumbuhan budi pekerti yang mencakup kekuatan batin dan karakter, pikiran dan tumbuh anak. Pendidikan juga dapat memajukan kesempurnaan hidup yang selaras dengan dunia. Dapat diartikan bahwa pendidikan adalah upaya untuk memajukan budi pekerti, pikiran serta jasmani anak agar dapat memajukan hidup dan menghidupkan anak yang selaras dengan alam dan masyarakat.

Pendidikan merupakan suatu keharusan bagi manusia sebagai upaya memanusiakan manusia. Pendidikan juga salah satu hak yang dapat diperoleh bagi semua warga negara Republik Indonesia sesuai dengan pasal 31 Undang-Undang Dasar 1945. Hal yang berkaitan dengan pendidikan sudah diatur dalam perundangundangan yang diamanatkan kepada pemerintah sebagai pelaksana UndangUndang yang diharapkan hak mendapatkan pendidikan diperoleh seluruh warga negara Indonesia.
Wajib belajar yang merupakan program pendidikan minimal yang wajib diikuti oleh warga negara Indonesia, pemerintah dan pemerintah daerah yang bertanggung jawab dalam terlaksananya program wajib belajar. Pendidikan agama mempunyai peranan khusus dalam membentuk moral karena agama mengatur hubungan manusia dengan Tuhan, hubungan manusia dengan sesamanya, hubungan manusia dengan alam dan hubungan manusia dengan dirinya yang menjamin keseimbangan, keserasian dan keselarasan hidup manusia sebagai pribadi maupun sebagai anggota masyarakat.

Pemerintah dalam hal ini membuat peraturan yang khusus mengatur pendidikan agama yaitu Peraturan Pemerintah Nomor 55 tahun 2007 bahwa, Pendidikan Agama memberikan pengetahuan, membentuk sikap, kepribadian dan keterampilan peserta didik dalam menjalankan ajaran agamanya. Pendidikan Agama juga harus diakui sebagai pembentuk karakter dan landasan dalam menjalankna segala aktifitas serta dalam menjalani kehidupan bermoral. Dapat diartikan bahwa pendidikan agama juga berkaitan dalam pembentukan karakter peserta didik (Thomas Lickona, 2013).

Satuan Pendidikan di wilayah Dinas Pendidikan Kabupaten Bantul terdapat dua peserta didik yang menganut Penghayat Kepercayaan. Agar tidak merasa didiskriminasi karena agama yang dianutnya berbeda dari agama yang sebelumnya sudah disahkan pemerintah yaitu: Islam, Kristen, Katolik, Hindu, Budha dan Konghucu. Hal ini yang harus menjadi perhatian Dinas Pendidikan Kabupaten Bantul seperti layanan pendidikan agama seperti pengajar dan fasilitas yang sama dengan peserta didik yang lainnya. Sesuai dengan hasil dilapangan, bahwa peserta didik ini diajarkan oleh seorang guru yang berbeda dari paguyubannya. 
Layanan pendidikan Kepercayaan Terhadap Tuhan Yang Maha Esa pada satuan pendidikan sudah diatur dalam Peraturan Menteri Pendidikan dan Kebudayaan Republik Indonesia Nomor 27 tahun 2016, dengan peraturan yang sudah ditetapkan maka layanan bagi peserta didik Penghayat Kepercayaan dalam pelajaran agama haruslah terpenuhi. Maka sesuai dengan amanat Pembukaan UndangUndang Dasar Negara Republik Indonesia Tahun 1945 yaitu mencerdaskan kehidupan bangsa, negara harus menjalankan kewajibannya dalam memenuhi hak pendidikan bagi Penghayat Kepercayaan dalam menyediakan pendidikan seperti warga negara lainnya. Tidak ada diskriminasi dalam setiap pembelajaran peserta didik Penghayat Kepercayaan. Berdasarkan penjelasan yang sudah dipaparkan, bahwa pendidikan agama sangatlah penting di Satuan Pendidikan dalam membangun karakter dan moral siswa, tidak terkecuali bagi peserta didik penghayat kepercayaan karena mereka juga punya hak yang sama dalam memperoleh pendidikan.

\section{METODE PENELITIAN}

Penelitian ini menggunakan pendekatan kualitatif, data yang disajikan berbentuk verbal bukan angka. Menurut Jane Richie, penelitian kualitatif adalah penelitian yang bertujuan untuk menyajikan dunia social dan perspektivnya di dalam dunia dari segi konsep, perilaku, persepsi serta persoalan tentang manusia yang diteliti. Pada suatu penelitian kualitatif, manusia adalah instrumen yang mengumpulkan data dan hal ini dilakukan dengan pengamatan berperan serta, wawancara yang mendalam, dan juga pengumpulan dokumen (Moleong, 2005:134).

Penelitian ini juga menggunakan penelitian deskriptif termasuk dalam penelitian kualitatif, penelitian yang berusaha menggambarkan objeknya sesuai dengan kondisi yang ada. Dengan menggunakan metode deskriptif dapat memberikan suatu variasi permasalahan yang berkaitan dengan bidang pendidikan dan juga tingkah laku manusia (Sukardi, 2007:157). Studi deskriptif berupaya memperoleh deskripsi yang lengkap dan sesuai dengan situasi yang ada, dalam studi deskriptif desain berbentuk formal diperlukan untuk meyakinkan setiap deskripsi mencakup semua tahapan dan mencegah terkumpulnya data yang tidak dibutuhkan. Jadi penelitian deskrptif bukan untuk menguji suatu hipotesis tertentu melainkan untuk menggambarkan secara apa adanya dari suatu variabel, gejala atau keadaan.

Untuk mendapatkan data yang dibutuhkan peneliti agar sesuai dengan informasi ingin didapatkan dan mendapatkan tujuan yang dicapai, pada penelitian ini menggunakan beberapa teknik dalam pengumpulan data. Teknik pengumpulan data dapat dilakukan dengan dokumen, wawancara, angket, observasi atau pengamatan maupungabungan dari ketiganya (Sugiyono, 2007:137).

Analisis data merupakan proses mencari dan menyusun data secara sistematis yang diperoleh dari hasil wawancara, dokumentasi, catatan lapangan dengan mengorganisasikan data ke dalam kategori, menjabarkan ke unitunit, melakukan sintesa, menyusunnya ke dalam pola, memilih bagian yang penting dan yang akan dipelajari dan membuat suatu kesimpulan yang mudah dipahami diri sendiri maupun orang lain (Sugiyono, 2007: 244).

Milles dan Huberman berpendapat bahwa, aktifitas dalam analisis data kualitatif dilakukan berlangsung secara terus menerus hingga tuntas dan interaktif. Aktivitas dalam menganalisis data yaitu data reduction, data display dan conclusion drawing atau verification. Siklus analisis 
data Milles dan Huberman yang dijadikan sebagai pedoman analisis data pada penelitian ini yaitu reduksi data atau memilih hal-hal yang pokok, display data (penyajian data) dan drawing verifying (penarikan kesimpulan).

Penjelasan dari siklus analisis data menurut Mileles dan Huberman yaitu seaga berikut: Reduksi data yaitu memilih hal-hal yang pokok biasa disebut juga merangkum, memfokuskan pada hal-hal yang penting maka pada reduksi data, peneliti melakukan pengelompokan data yang diperlukan untuk penelitian. Display data atau penyajian data yaitu setelah data direduksi, langkah selanjutnya menyajikan data. Penyajian data biasa dilakukan dalam bentuk uraian singkat, bagan maupun hubungan antar kategori. Dalam penelitian kualitatif penyajian data menggunakan teks yang bersifat naratif selain dengan teks penyajian data juga dapat berupa grafik, matrik, jejaring kerja dan rencana (Sugiyono, 2007: 249). Penarikan kesimpulan merupakan temuan baru yang sebelumnya belum pernah ada. Temuan dapat berupa gambaran suatu objek yang sebelumnya masih kurang jelas sehingga setelah diteliti menjadi jelas dapat berupa hubungan interaksi dan hipotesis.

Analisis data pada penelitian kualitatif dilakukan saat pengumpulan data berlangsung dan setelah selesai pengumpulan data diperiode tertentu. Periode pengumpulan data yaitu data yang telah terkumpul dari hasil wawancara, tanggapan peneliti, foto, gambar, dokumen berrupa laporan dan data lainnya yang bermakna penelitian kemudian dibuat dengan catatan lapangan.

\section{HASIL PENELITIAN DAN PEMBAHASAN Hasil Penelitian}

Penghayat Kepercayaan masih mengalami diskriminasi, khususnya dalam penghormatan hak-hak sipilnya. Hal ini berakar dari "perbedaan" yang lahir dari pengakuan negara atas agama dan perlakuan berbeda kepada "agama" dan "kepercayaan". Pada Pemerintahan Joko Widodo-Jusuf Kalla salah satu agenda prioritas adalah memprioritaskan perlindungan terhadap anak, perempuan dan kelompok masyarakat termajinalkan, serta penghormatan HAM dan penyelesaian secara berkeadilan terhadap kasus-kasus pelanggaran HAM pada masa lalu menjadi momentum tepat untuk penegakan HAMnya.

Tulisan yang didasarkan pada penelitian bersifat deskriptif analisis dengan pendekatan yuridis normatif pada tataran implementasi (khususnya Kota Bandung), para penghayat kepercayaan tidak mengalami kendala dalam memperoleh layanan kependudukan dan catatan sipil. Namun demikian masih terdapat penolakan masyarakat umum terhadap pemakaman bagi para penghayat kepercayaan di tempat pemakaman umum. Penolakan ini tentu bertentangan dengan Pasal 8 ayat (2) Peraturan Bersama Menteri Dalam Negeri dan Menteri Kebudayaan dan Pariwisata Nomor 43 Tahun 2009 dan Nomor 41 Tahun 2009 tentang Pedoman Pelayanan Kepada Penghayat Kepercayaan Kepada Tuhan Yang Maha Esa, maka pemerintah daerah menyediakan pemakaman umum.

Perlindungan hukum bagi penghayat kepercayaan dari penghinaanterhadap aliran kepercayaannya dibahas pada oleh Widya Dita di Hukum Student Journal Tahun 2017 dengan judul "Urgensi Pengaturan Perlindungan Hukum Bagi Penghayat Kepercayaan Dari Penghinaan Terhadap Aliran Kepercayaannya". Jurnal ini menyatakan bahwa Saat ini masih banyak aliran- aliran kepercayaan yang masih ada dan terus berjalan di Indonesia. Aliran kepercayaan merupakan agama lokal yang ada di Indonesia yang juga merupakan agama turun-temurun dari leluhurnya atau nenek moyang. Namun 
sayangnya aliran kepercayaan ini belum mendapatkan perlindungan hukum yang maksimal dari Negara.

Bahan hukum primer dan sekunder kemudian akan dianalisa secara deskriptif agar ditemukan sesuatu yang semula bersifat umum, kemudian dikategorikan dan disusun secara sistematis. Dari hal tersebut akan ditemukan alasan urgensi pengaturan perlindungan hukum bagi aliran kepercayaan. Sehingga dapat dibentuk konsep perundang-undang baru tentang perlindungan hukum bagi aliran kepercayaan di Indonesia. Karena pada hakikatnya hak kebebasan beragama merupakan hak yang secara mutlak dimiliki oleh setiap warga Negara tanpa terkecuali. Tak peduli walaupun dari golongan penghayat kepercayaan atau umat agama resmi di Indonesia.

Jurnal Konstitusi yang berjudul "Akibat Hukum Pemisahan Hak Beragama dengan Hak Berkepercayaan dalam Undang-Undang Dasar Negara Republik Indonesia Tahun 1945" oleh Muwaffiq dan Mukhlis mengatakan pemisahan agama dan kepercayaan dalam konstitusi adalah suatu kebijakan yang menimbulkan beragam masalah. Seringkali para Penghayat Kepercayaan mengalami intimidasi ataupun hal-hal lain yang mengganggu pelaksanaan hak sipilnya untuk menganut dan mengamalkan ajaran kepercayaan yang dianutnya. Dengan dalih kepercayaan bukan agama, para pelaku anarkisme seringkali melakukan pelarangan dan kekerasan terhadap para penganut kepercayaan. Kajian ini menggunakan metode penelitian hukum normatif.

Sedangkan hasil penelitiannya ialah bahwa 1) Alasan hukum pemisahan pengaturan antara agama dengan aliran kepercayaan disebabkan oleh politik pembedaan pendefinisian keduanya dimana kepercayaan diamsusikan sebagai tradisi dan ajaran luhur masyarakat yang bersumber dari budaya yang keberadaannya di luar agama. 2) Pemisahan agama dan kepercayaan berakibat hukum tidak diakuinya aliran kepercayaan sebagai agama resmi negara, padahal status aliran kepercayaan merupakan agama local yang diyakini sebagai agama oleh para penganutnya. Pemisahan ini juga mengakibatkan hadirnya beragam sikap diskriminatif yang berpotensi menggangguu dan merampas hak setiap warga negara dalam meyakini suatu agama dalam hal ini hak beragama yang diganggu dan dirampas ialah hak untuk meyakini agama local sebagai agama warisan leluhur bangsa Indonesia.

Jurnal oleh Dian Kurnia Sari di Jurnal Ilmu-Ilmu Ushuludin Tahun 2018 dengan judul "Nasionalisme Sebagai Ajaran Spritual Penghayat" menyatakan bahwa Nasionalisme merupakan ajaran sipritual yang sakral bagi pelaku Penghayat, khususnya Kaweruh Jowo Dipo. Ajaran sakral ini mengusung semangat menjaga Nusantara. Asumsi penjagaan terhadap Nusantara merupakan bagian dari penjagaan warisan leluhur untuk keharmonisan hidup berbangsa. Kelompok agama seperti Kaweruh Jowo Dipo mempunyai andil dalam meneguhkan dan merawat ajaran sakral ini. Penelitian ini memfokuskan pada satu titik, bagaimana ajaran nasionalisme ini menjadi ajaran spiritual bagi kelompok Penghayat Kaweruh Jowo Dipo. Penelitian ini menggunakan jenis penelitian kualitatifdeskriptif. Dengan metode spesifik, etnografi-basis Native Point of View.

Adapun hasil dari penelitian ini menunjukkan bahwa ajaran nasionalisme diserap dari ajaran nenek moyang yang berperikemanusiaan. Ajaran ini dikemas melalui kidung dan laku para penganut penghayat Kaweruh Jowo Dipo. Doktrinya, nasionalisme menjadi salah satu mantra menuju laku yang humanis.

Jurnal Penelitian Keagamaan dan 
Masyarakat oleh Zakiyah VOL 31 Nomor 2 tahun 2018 dengan judul "Pendidikan Kepercayaan Terhadap Tuhan Yang Maha Esa : Pemenuhan Hak Siswa Penghayat di Sekolah" membahas masalah Pendidikan Kepercayaan terhadap Tuhan Yang Maha Esa di sekolah bagi siswa siswi penghayat Kepercayaan. Tema ini penting untuk dikaji karena masih banyak sekolah yang belum memberikan mata pelajaran "Pendidikan Kepercayaan" karena berbagai alasan seperti belum adanya perangkat pendukungnya dan adanya pandangan pendidikan Kepercayaan ini bukan merupakan "Pendidikan Agama" sebagaimana di atur dalam perundangundangan.

Data dalam tulisan ini diambil dari hasil penelitian yang telah dilakukan pada tahun 2016. Adapun penelitian tersebut menggunakan pendekatan kualitatif dan data dikumpulkan dengan menggunakan metode wawacara dan studi pustaka terhadap dokumen terkait dengan topik penelitian. Riset ini dilakukan di Kabupaten Cilacap dengan pertimbangan di daerah ini terdapat sekolah-sekolah yang telah memberikan pendidikan Kepercayaan terhadap Tuhan YME bagi peserta didiknya. Data yang terkumpul dianalisis dengan menggunakan perpektif Hak Asasi Manusia.

Hasil studi ini menunjukkan bahwa terdapat 14 sekolah mulai dari Sekolah Dasar, Sekolah Menengah Pertama hingga Sekolah Menengah Atas yang telah memberikan layanan pendidikan tersebut. Dalam pelaksanaannya mereka bekerjasama dengan MLKI Cilacap dalam hal penyediaan guru, materi, silabut, KIKD dan soal-soal tes. Hal ini merupakan gambaran pemenuhan hak dasar bagi anak-anak untuk mendapatkan pendidikan agama sesuai dengan keyakinannya.

\section{Pembahasan}

Berdasarkan paparan data dan temuan yang telah disajikan kebijakan pemerintah tentang layanan pendidikan bagi siswa Penghayat Kepercayaan yaitu, Penghayat Kepercayaan merupakan istilah yang diberikan negara bagi pemeluk keyakinan diluar enam agama yang diakui di Indonesia selain itu Penghayat Kepercayaan adalah setiap orang yang mengakui dan meyakini nilai-nilai Penghayat Keperayaan Terhadap Tuhan Yang Maha Esa.

Penghayat Kepercayaan merupakan salah satu kaum minoritas yang ada di Indonesia. Sehingga kebijakan pemerintah yang berkaitan dengan Penghayat Kepercayaan, baik pengakuan dari negara, pencatatan sipil, dan perkawinan yang sah di mata negara tidak terkecuali kebijakan tentangpendidikan keagamaan bagi siswa Penghayat Kepercayaan yang lama diperjuangkan haknya oleh Penghayat Kepercayaan. Kebijakan mengenai pendidikan keagamaan bagi siswa Penghayat Kepercayaan belum lama ini baru dikeluarkan. Padahal pendidikan merupakan salah satu hak dasar negara yang harus dipenuhi oleh negara sesuai dengan amanat Pembukaan UndangUndang Dasar Negara Republik Indonesia Tahun 1945 yaitu mencerdaskan kehidupan bangsa dan sesuai dengan Pasal 31 ayat 1 Undang-Undang Dasar Tahun 1945 yang berbunyi bahwa setiap warga negara berhak mendapat pendidikan.

Maka negara haruslah menjalankan kewajibannya dalam Memenuhi hak pendidikan terhadap Penghayat Kepercayaan untuk mendapatkan pendidikan agama sesuai dengan kepercayaan yang diyakininya. Selama ini kebijakan pemerintah tentang pendidikan agama hanya terfokus pada enam agama yang diakui oleh negara. Layanan Penghayat Kepercayaan sendiri sudah ditetapkan sejak tahun 2009 yang terdapat pada Peraturan Bersama Menteri Nomor 43/41 tahun 2009 tentang Pedoman 
Layanan Kepada Penghayat Kepercayaan Kepada Tuhan Yang Maha Esa. Tetapi kebijakan layanan pendidikan agama bagi Penghayat Kepercayaan baru ditetapkan pada tahun 2016 yang terdapat pada Peraturan Menteri Pendidikan dan Kebudayaan Republik Indonesia Nomor 27 tahun 2016 tentang Layanan Pendidikan Kepercayaan Terhadap Tuhan Yang Maha Esa Pada Satuan Pendidikan. Hal tersebut dapat dikatakan bahwa pemerintah kurang cepat mengambil tindakan dalam kebijakan pendidikan bagi Penghayat Kepercayaan.

Pada Peraturan Menteri Pendidikan dan Kebudayaan Republik Indonesia Nomor 27 tahun 2016 terdapat berbagai peraturan maupun hak layanan pendidikan dan pembelajaran bagi Penghayat Kepercayaan. Diantaranya menyebutkan tenaga kependidikan yang berkualifikasi sebagai guru (pamong belajar) sesuai dengan kekhususannya, adanya kurikulum, muatan Pendidikan Kepercayaan memiliki Kompetensi Inti dan Kompetensi Dasar, Silabus, Rencana Pelaksanaan Pembelajaran, buku teks pelajaran. Agar berlangsungnya penyediaan Pendidikan Kepercayaan, Pemerintah maupun Pemerintah Daerah dan satuan pendidikan (sekolah) dapat bekerja sama dengan Organisasi Penghayat Kepercayaan Kepada Tuhan Yang Maha Esa yang telah terdaftar.

Kebijakan Peraturan Menteri Pendidikan dan Kebudayaan Republik Indonesia Nomor 27 tahun 2016 sudah cukup jelas tentang layanan pendidikan bagi siswa Penghayat Kepercayaan. Dengan peraturan yang sudah ditetapkan tersebut harapannya sesuai dengan realita keadaan yang diterima oleh siswa Penghayat Kepercayaan dan sudah terpenuhi.

Berdasarkan paparan data dan temuan yang telah disajikan maka pelaksanaan pemenuhan layanan pembelajaran pendidikan bagi siswa Penghayat Kepercayaan di wilayah Dinas Pendidikan Kabupaten Bantul ditetapkan dalam Peraturan Menteri Pendidikan dan Kebudayaan Republik Indonesia Nomor 27 tahun2016 tentang layanan pendidikan bagi Penghayat Kepercayaan, menandakan bahwa layanan pendidikan bagi Penghayat Kepercayaan harusnya sudah terpenuhi dan diterima oleh siswa Penghayat Kepercayaan dari segala layanan yang sudah ditetapkan dalam peraturan tersebut. Tidak terkecuali bagi siswa Penghayat Kepercayaan yang bersekolah di wilayah Dinas Pendidikan Kabupaten Bantul. Di wilayah Dinas Pendidikan Kabupaten Bantul terdapat sekolah yang mempunyai siswa Penghayat Kepercayaan, sekolah tersebut tepatnya di SMK Negeri 1 Kasihan. Ada dua siswa Penghayat Kepercayaan yang bersekolah di SMK Negeri 1 Kasihan.

Siswa Penghayat Kepercaayaan mendaftarkan diri di SMK Negeri 1 Kasihan pada Tahun Ajaran 2017/2018. Sekolah sudah menerima siswa dengan baik. Pihak sekolah tidak pernah memaksakan siswa Penghayat Kepercayaan untuk mengikuti pelajaran keagamaan yang sudah ada di sekolah. Pihak sekolah juga gerak cepat dalam mencarikan seorang pengajar Penghayat Kepercayan dan mengajukan data siswa serta meminta kebijakan lebih lanjut terhadap siswa Penghayat Kepercayaan dari Pemerintah Daerah.

Awal kegiatan pembelajaran pendidikan Penghayat Kepercayaan tidak berjalan sesuai yang diharapkan, siswa menunggu keputusan lebih lanjut tentang haknya dalam pembelajaran maupun segala urusannya di sekolah dari Pemerintah Daerah selama enam bulan atau satu semester, walaupun sekolah sudah menyediakan seorang pengajar. Sekolah tidak ingin salah dalam melakukan tindakan dan mengambil keputusan maka menunggu keputusan dari Pemerintah Daerah. Selama menungu hampir enam bulan, siswa mengikuti pembelajaran pendidikan keagamaan yang tidak sesuai 
dengan kepercayaannya. Hingga pergantian semester masih belum ada kejelasan dari Pemerintah Daerah akhirnya sekolah memutuskan sendiri mengenai keberlangsungan kegiatan pembelajaran pendidikan Penghayat Kepercayaan. Dikarenakan sudah terlalu lama siswa menunggu dan sudah tertinggal banyak materi yang harusnya diterima. Kegiatan pembelajaran pendidikan Penghayat Kepercayaan sempat dilakukan di ruang pendidikan agama Katolik selama satu semester dan hingga saat ini pembelajaran dilakukan di perpustakaan.

Kurikulum pendidikan Penghayat Kepercayaan hingga saat ini masih dalam tahap perbaikan, dari awal siswa Penghayat Kepercayaan mengikuti pembelajaran pendidikan Penghayat Kepercayaan hingga saat ini masih belum ada kurikulum yang tetap atau jelas. Hal ini juga bepengaruh pada tersedianya buku teks atau buku pembelajaran pendidikan Penghayat Kepercayaan.

Di kelas 10 hingga saat ini duduk di kelas 12, siswa Penghayat Kepercayaan tidak pernah belajar dengan menggunakan buku teks ataupun sejenisnya. Siswa belajar maupun melakukan pembelajaran menggunakan materi berbentuk softfile yang dikirimkan pengajar Penghayat Kepercayaan melalui ponsel, diharapkan siswanya dapat belajar dan memahami materi walaupun dengan keterbatasan. Bukan sekolah tidak menyediakan maupun mencarikan buku teks atau buku pelajaran. Pemerintah memang belum mengeluarkan maupun menerbitkan materi pendidikan Penghayat Kepercayaan dalam bentuk wujud buku.

Di SMK Negeri 1 Kasihan siswa dan guru Penghayat Kepercayaan berasal dari Paguyuban/ Organisai Penghayat Kepercayaan yang berbeda. Dua siswa berasal dari Paguyuban Palang Putih Nusantara sedangakan guru berasal dari Paguyuban Trisoka. Hal tersebut tidak dijadikan sebuah penghambat dalam pembelajaran, karena dalam materi yang dipelajari diambil dari garis besar paguyuban yang ada di Indonesia. Untuk pelaksanaan ujian sekolah maupun ujian akhir, siswa Penghayat Kepercayaan mengikuti ujian seperti siswa lainnya. Soal yang diberikan merupakan soal yang dibuat oleh guru Penghayat Kepercayaan yang kemudian soal disetorkan pada pihak sekolah. Dan untuk ujian akhir sekolah, soal juga dibuat oleh guru Penghayat Kepercayaan. Soal dibuat sesuai dengan materi yang sudah dipelajari siswa.

Siswa Penghayat Kepercayaan di SMK Negeri 1 Kasihan hingga saat ini tidak pernah mendapatkan perlakuan yang tidak baik seperti diskriminasi baik dari pihak guru maupun siswa lainnya. Dikarenakan sekolah yang berlatar belakang kebudayaan dan siswa yang bersekolah tidak hanya berasal dari Yogyakarta melainkan dari berbagai daerah yang ada di Indonesia, membuat masyarakat sekolah menyikapi sebuah perbedaan merupakan hal yang sudah biasa. Siswa maupun guru dan masyarakat sekolah saling menghormati perbedaan yang ada dan saling bertoleransi pada keyakinan yang berbeda.

\section{KESIMPULAN}

Berdasarkan hasil penelitian tentang pemenuhan layanan pembelajaran bagi siswa Penghayat Kepercayaan di wilayah Dinas Pendidikan Kabupaten Bantul dapat disimpulkan, bahwa kebijakan pemerintah tentang pendidikan bagi Penghayat Kepercayaan. Kebijakan tersebut sudah diatur dalam Peraturan Menteri Pendidikan dan Kebudayaan Republik Indonesia Nomor 27 tahun 2016 tentang Layanan Pendidikan Kepercayaan Terhadap Tuhan Yang Maha Esa Pada Satuan Pendidikan. Peraturan di dalamnya menyebutkan bahwa peserta didik Penghayat Kepercayaan Terhadap Tuhan 
Yang Maha Esa berhak mendapatkan Layanan Pendidikan Kepercayaan Terhadap Tuhan Yang Maha Esa sesuai dengan hak-hak peserta didik dengan menjunjung tinggi hak asasi manusia.

Mengetahui pelaksanaan pemenuhan layanan pembelajaran Pendidikan bagi Penghayat Kepercayaan di wilayah Dinas Pendidikan Kabupaten Bantul. Siswa Penghayat Kepercayaan di wilayah Dinas Pendidikan Kabupaten Bantul tepatnya berlokasi di SMK Negeri 1 Kasihan, belum sepenuhnya terpenuhi layanan pembelajaran pendidikannya. Hal ini dibuktikan dengan belum adanya Kurikulum yang jelas dan juga belum tersedianya buku teks sebagai penunjang pembelajaran. Belum tersedianya pendidik yang sesuai dengan siswa atau berasal dari Paguyuban/Organisasi yang sama, walaupun di SMK Negeri 1 Kasihan hal tersebut tidak menjadikan sebuah hambatan dalam berlangsungnya Pembelajaran. Pemerintah Daerah yang masih belum bertindak cepat dalam menangani siswa Penghayat Kepercayaan. Beberapa hal yang menjadi kurang terpenuhinya layanan pembelajaran pendidikan bagi siswa Penghayat Kepercayaan tersebut berdasarkan dengan isi di dalam Peraturan Menteri Pendidikan dan Kebudayaan Republik Indonesia Nomor 27 tahun 2016 tentang Layanan Pendidikan Kepercayaan Terhadap Tuhan Yang Maha Esa Pada Satuan Pendidikan.

\section{DAFTAR PUSTAKA}

Budijanto, W. 2016. "Penghormatan Hak Asasi Manusia Bagi Penghayat Kepercayaan Di Kota Bandung”. (hlm 35 - 44). Jakarta: Badan Penelitian Dan Pengembangan Hukum Dan HAM Kementrian Hukum Dan HAM RI.

Dian, Kurnia. 2018. "Nasionalisme Sebagai Ajaran Spritual Penghayat”. KONTEMPLASI Jurnal Ilmu-ilmu Ushuludin, 6(1).

Lickona, Thomas. 2013. Pendidikan Karakter; Panduan Lengkap Mendidik Siswa Menjadi Pintar dan Baik. Bandung: Nusa Media.

Muwaffiq, dan Mukhlish. 2019. "Akibat Hukum Pemisahan Hak Beragama dengan Hak Berkepercayaan dalam Undang-Undang Dasar Negara Republik Indonesia Tahun 1945”. Jurnal Konstitusi 16(2).

Moleong, Lexy J. 2010. Metodologi Penelitian Kualitatif. Edisi revisi. Bandung: PT Remaja Rosadakarya

Peraturan Menteri Pendidikan Dan Kebudayaan Republik Indonesia Nomor 27 Tahun 2016 Tentang Layanan Pendidikan Kepercayaan Terhadap Tuhan Yang Maha Esa Pada Satuan Pendidikan.

Sugiyono. 2007. Metode Penelitian Administrasi. Bandung: Alfabeta.

Sugiyono .2013. Metode Penelitian Pendidikan Pendekatan Kuantitatif, Kualitatif, dan R\&D. Bandung: Alfabeta.

Sukardi. 2007. Metodologi Penelitian Pendidikan. Jakarta: Bumi Aksara.

Undang-Undang Dasar Negara Republik Indonesia Tahun 1945

Undang-Undang Republik Indonesia Nomor 20 Tahun 2003 Tentang Sistem Pendidikan Nasional

Widya, Dita. 2017. "Urgensi Pengaturan Perlindungan Hukum Bagi Penghayat Kepercayaan Dari Penghinaan Terhadap Aliran Kepercayaannya". Hukum Student Journal

Zakiyah. 2018. "Pendidikan Kepercayaan Terhadap Tuhan Yang Maha Esa: Pemenuhan Hak Siswa Penghayat Di Sekolah". Penamas Jurnal Penelitian Keagamaan Dan Masyarakat, $31(2)$. 